\title{
再论南岭燕山早期花岗岩的成因类型与构造意义
}

\begin{abstract}
李献华 ${ }^{\oplus 0}$ 李武显 ${ }^{\circledR}$ 李正祥 ${ }^{\oplus}$
(1) 中国科学院广州地球化学研究所同位素年代学和地球化学重点实验室, 广州 510640; (2) 中国科学院地质与地球物理研究所岩石 圈演化国家重点实验室, 北京 100029; (3) Institute of Geoscience Research, Department of Applied Geology, Curtin University of Technology, GPO Box U1987, Perth WA 6845, Australia. E-mail: lixh@gig.ac.cn)

摘要 中国东南部南岭地区广泛出露的燕山早期(侏罗纪)花岗岩与稀有金属成矿作用有非常密切的关 系, 这些花岗岩以弱过铝质黑云母二长花岗岩和黑云母钾长花岗岩为主, 并和一些规模较小的含角闪 石花岗岩和含白云母石榴子石的浅色花岗岩在时-空上密切共生. 在以往的文献中, 这些黑云母花岗 岩一般被认为是陆壳改造型(相当于 $\mathrm{S}$ 型)花岗岩, 是区域元古代变质沉积岩重熔的产物. 对南岭燕山早 期一些代表性花岗岩的岩石化学特征和 $\mathrm{SiO}_{2}-\mathrm{P}_{2} \mathrm{O}_{5}$ 相关关系进行了系统的分析研究, 结果显示这些花岗 岩的 $\mathrm{SiO}_{2}-\mathrm{P}_{2} \mathrm{O}_{5}$ 均呈明显的负相关关系, 表明南岭燕山早期的含角闪石花岗闪长岩-黑云母二长花岗岩黑云母钾长花岗岩-二(白)云母花岗岩为准铝质-弱过铝质的 I 型/分异 I 型花岗岩演化系列, 其源岩主要 为元古代火成岩, 少量新生地壳和/或地幔分异物质很可能参与了花岗岩的形成. 同时, 这些 I 型/分异 I 型花岗岩在时空上和 A 型酸性、基性火山/侵入岩以及碱性岩密切共生, 构成了一个比较典型的板内非 造山火成岩组合, 反映了燕山早期南岭及邻区大陆岩石圈以伸展背景为主.
\end{abstract}

关键词 花岗岩 成因分类 燕山早期 南岭 华南 岩石圈伸展

南岭地区广泛出露花岗岩, 其中大部分是燕山 早期(侏罗纪)花岗岩(图 1), 与稀有金属矿产有非常 密切的关系, 是中国花岗岩与成矿作用研究的摇篮. 在 20 世纪 80 年代, 南岭花岗岩的成因分类研究基本 上与国际同类研究同步，如Xu 等人 ${ }^{11}$ 提出的同熔 型、陆壳改造型和幔源型, 在中国的花岗岩研究中得 到比较广泛的应用; 王联魁等人 [2]提出的“南岭系列” 和“长江系列”两个花岗岩成岩成矿序列, 则侧重于 花岗岩的演化系列及其与成矿作用的关系. 20 世纪 90 年代以后, 随着大量同位素地球化学资料的积累, 对同熔型和改造型花岗岩的物质来源研究有了长足 的进步. 目前一般的认识是同熔型花岗岩是指地幔 和地壳物质的“混源”和两个端元物质的相互作用形 成的, 相当于I型花岗岩, 而改造型花岗岩主要由元 古代变质沉积岩经部分熔融形成, 相当于 $S$ 型花岗岩 [3,4].

随着同位素年代学分析技术的进步, 特别是近 年来高分辨率高灵敏度离子探针的引进和应用, 华 南各类火成岩积累了相当数量的高质量年代学数据 资料. 图 2 是南岭及邻区燕山早期火成岩高精度年龄 的汇总 ${ }^{[5]}$, 显示主要集中在两个阶段, 即第 I 阶段的
180 170 Ma和第 II 阶段的 165 150 Ma.

燕山早期最早的花岗岩浆活动记录是赣南的柯 树北岩体(SHRIMP锆石U-Pb年龄为 $(189 \pm 3) \mathrm{Ma}^{[6]}$ ) 和 湖南沩山巷子口岩体 (LA-ICPMS 锆石 U-Pb年龄为 $\left.(187 \pm 4) \mathrm{Ma}^{[7]}\right)$.

第 I 阶段(180 170 Ma)的岩浆活动规模比较小. 目前可靠的年代学资料显示这个阶段的岩浆活动 主要是陆续分布于湘南-赣南-闽西南的双峰式火山 岩、赣南地区的铝质 $\mathrm{A}$ 型花岗岩和共生的辉长岩 [8 12]、以及湘东南与铜多金属矿有关的一些花岗闪长 岩小岩体 ${ }^{[13]}$ 和赣东北赋存超大型斑岩铜矿的德兴石 英闪长质-花岗闪长质斑岩 ${ }^{[14]}$.

第 II 阶段(165 150 Ma)花岗岩规模巨大, 构成南 岭及邻区燕山早期花岗岩的主体. 岩石类型以黑云 母花岗岩为主(包括许多出露面积 $>500 \mathrm{~km}^{2}$ 的大型花 岗岩基), 同时伴有少量偏中性的花岗闪长岩、超酸性 的二(白)云母花岗岩、A型花岗岩和钾质碱性正长岩 侵入体以及湘南道县地区很小规模的 “高镁玄武 岩”[11].

值得注意的是南岭燕山早期花岗岩一个重要的 岩相学特征是黑云母花岗岩占绝大多数. 这些花岗 


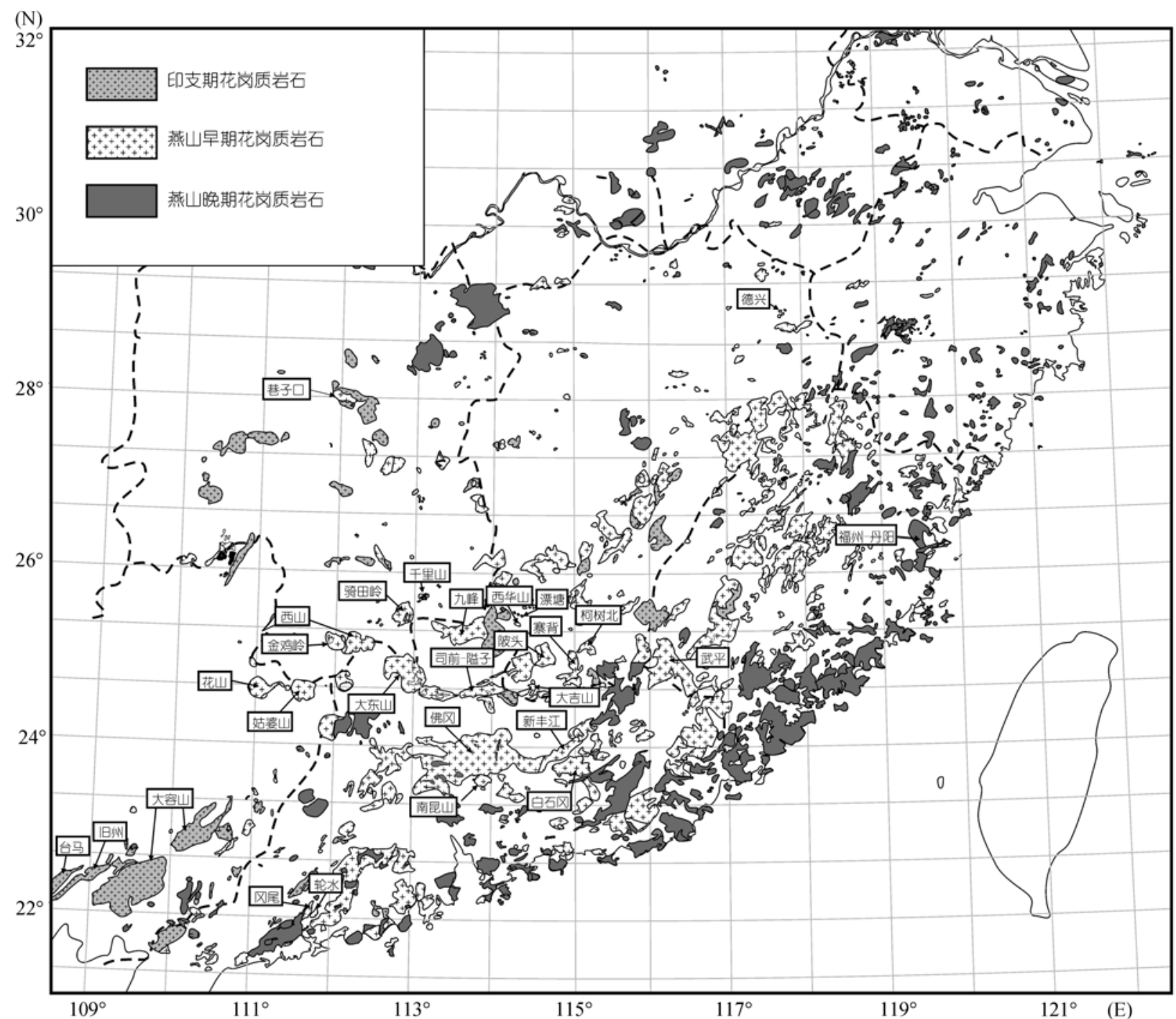

图 1 南岭及邻区中生代花岗岩分布概图及本研究涉及的岩体

岩在岩石化学上通常为弱过铝质, 造岩矿物为黑云 母、石英和两种长石, 既不含I型花岗岩的特征矿物角 闪石, 也没有 $\mathrm{S}$ 型花岗岩的特征富铝矿物. 同时, 黑 云母花岗岩也常常和一些出露规模较小的含角闪石 的花岗闪长岩/二长花岗岩和含白云母石榴子石的 浅色花岗岩在时-空上密切共生, 组成典型的“南岭系 列”花岗岩 [2], 即: 二长花岗岩 $\rightarrow$ 黑云母花岗岩 $\rightarrow$ 浅 色(白云母或二云母)花岗岩 $\rightarrow$ 花岗斑岩/石英斑岩系 列, 其中含角闪石的花岗闪长岩/二长花岗岩和浅色 (白云母或二云母)花岗岩的矿物组成和铝饱和指数 分别和I型和S型花岗岩相对应. 这个系列的花岗岩 在岩石地球化学上常显示出与典型I型或 $S$ 型花岗岩 一些不同或过渡的特征, 因此造成了成因类型划分
上的困难和争议, 例如对佛冈花岗岩(出露面积 $>6000 \mathrm{~km}^{2}$, 是南岭最大和最有代表性的花岗岩基)就 有S型、I型和铝质A型花岗岩的不同认识 ${ }^{[15 ~ 18]}$.

本文将根据磷灰石在准铝质和强过铝质花岗岩 浆中溶解度不同的性质, 通过花岗岩的 $\mathrm{SiO}_{2}$ 与 $\mathrm{P}_{2} \mathrm{O}_{5}$ 的相关性判断其母岩浆的铝饱和度, 为南岭燕山早 期花岗岩的成因分类提供进一步的岩石化学依据, 并探讨这些花岗岩形成的地球动力学背景.

\section{1 花岗质岩浆中磷灰石的溶解度}

\section{1 前人的实验结果}

磷灰石富集 REE, Th 和 U, 是花岗岩中的主要副 矿物之一 ：在花岗岩浆结晶分异演化过程中, 磷灰石 

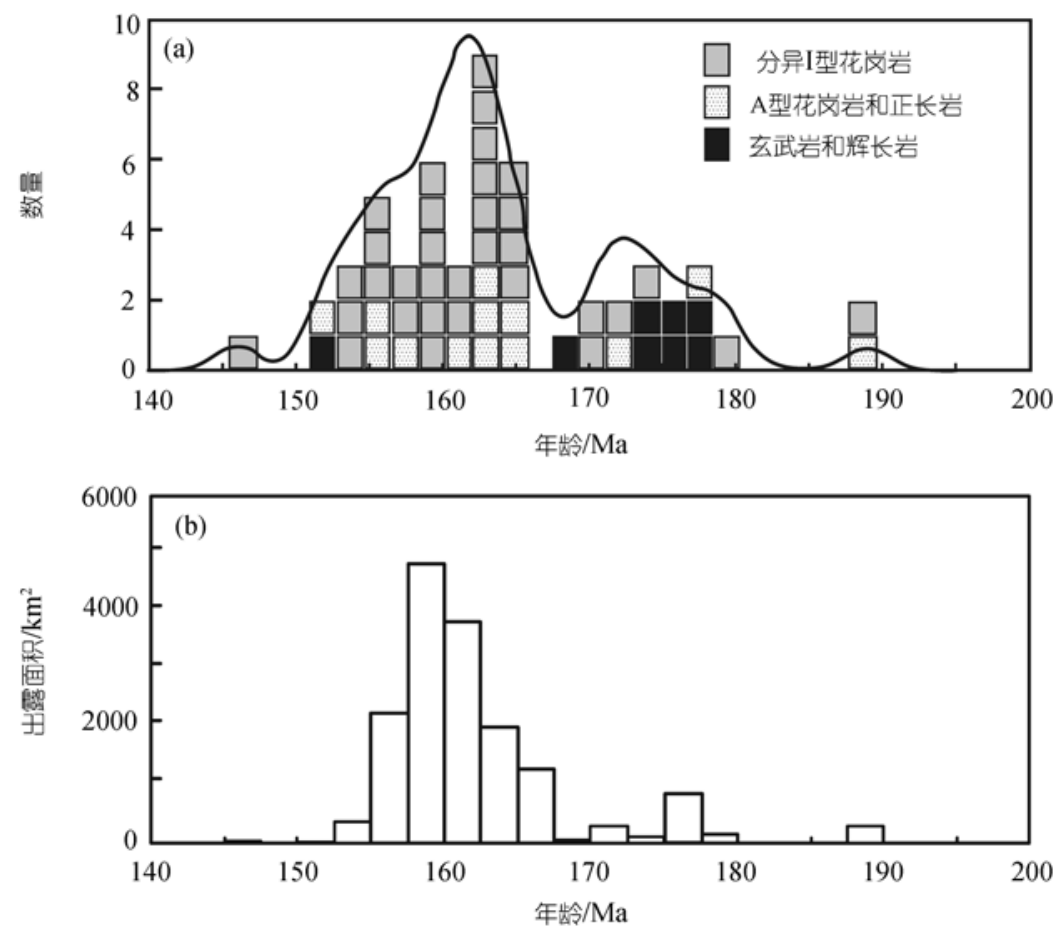

图 2 南岭及邻区燕山早期花岗岩的年龄统计图(a)和相应岩体的出露面积统计图(b) (据 $\mathrm{Li}$ 等人 ${ }^{[5]}$ )

对REE, Th和U等元素的变化有非常重要的影响. 大 量的实验研究结果表明, 在准铝质/弱过铝质 $(\mathrm{A} / \mathrm{CNK}$ $<1.1)$ 和过碱性花岗岩浆中, 磷灰石的溶解度很低, 大约只有 $0.1 \mathrm{wt} \%$ (wt\%表示质量分数, 下同) $\mathrm{P}_{2} \mathrm{O}_{5}$, 并且磷灰石的溶解度随着温度的降低和岩浆的分异 演化 $\mathrm{SiO}_{2}$ 的增加而降低; 相反, 在强过铝质岩浆中 (A/CNK为 1.1 1.3), 磷灰石的溶解度随 $\mathrm{A} / \mathrm{CNK}$ 的增 加而呈线形增加, 当 $\mathrm{A} / \mathrm{CNK}$ 为 1.3 时, $\mathrm{P}_{2} \mathrm{O}_{5}$ 可高达 $0.63 \mathrm{wt} \%{ }^{[19 \sim 23]}$. 这些实验结果的重要意义是证明了 磷灰石在准铝质/弱过铝质和过碱性花岗岩浆中总是 优先结晶的矿物, 而残余岩浆的 $\mathrm{P}_{2} \mathrm{O}_{5}$ 越来越低, 因此 I型和 $\mathrm{A}$ 型花岗岩的 $\mathrm{P}_{2} \mathrm{O}_{5}$ 将随着 $\mathrm{SiO}_{2}$ 的增高而降低, 并导致强分异 $\mathrm{I}$ 型和 $\mathrm{A}$ 型花岗岩的 $\mathrm{P}_{2} \mathrm{O}_{5}$ 含量非常低; 相反, 高的溶解度使磷灰石在强过铝质花岗岩浆中 主要呈不饱和状态而不会优先结晶(花岗岩中的 $\mathrm{P}_{2} \mathrm{O}_{5}$ 一般小于 $0.4 \%$, 很少达到 $\mathrm{P}_{2} \mathrm{O}_{5}$ 的最高饱和浓度), 因 此 $\mathrm{S}$ 型花岗岩的 $\mathrm{P}_{2} \mathrm{O}_{5}$ 将随着 $\mathrm{SiO}_{2}$ 的增加而呈增高或基 本不变的趋势. S型花岗岩高度分异后的残余熔浆中, $\mathrm{Al}^{3+}+\mathrm{P}^{5+}$ 置换 $2 \mathrm{Si}^{4+}, \mathrm{P}$ 可以进入到碱性长石, 使少数 强分异 $S$ 型花岗岩和花岗质伟晶岩有很高的 $\mathrm{P}_{2} \mathrm{O}_{5}$ 含量 [24,25].

1.2 典型 $\mathrm{I}$ 型和 $\mathrm{S}$ 型花岗岩的 $\mathrm{SiO}_{2}-\mathrm{P}_{2} \mathrm{O}_{5}$ 相关关系 Chappell ${ }^{[26]}$ 系统总结了澳大利亚Lachlan褶䏢带
中I型和S型花岗岩的 $\mathrm{SiO}_{2}-\mathrm{P}_{2} \mathrm{O}_{5}$ 相关关系(图 3), 所有I 型花岗岩的 $\mathrm{P}_{2} \mathrm{O}_{5}$ 随 $\mathrm{SiO}_{2}$ 增加而降低, 特别是当 $\mathrm{SiO}_{2}$ $>75 \%$ 时, 绝大多数样品的 $\mathrm{P}_{2} \mathrm{O}_{5}<0.05 \%$; 而 $\mathrm{S}$ 型花岗 岩的 $\mathrm{SiO}_{2}$ 和 $\mathrm{P}_{2} \mathrm{O}_{5}$ 分布在一个非常分散的 “三角形” 区 域，从偏基性端的 $\mathrm{P}_{2} \mathrm{O}_{5} \approx 0.15 \%$ 向超酸性端的两个方 向演化, $\mathrm{P}_{2} \mathrm{O}_{5}$ 从 $~ 0.02 \%$ 变化到 $0.42 \%$. 大多数酸性 $\mathrm{S}$ 型花岗岩的 $\mathrm{P}_{2} \mathrm{O}_{5}>0.1 \%$. 只有很少酸性 $\mathrm{S}$ 型花岗岩的 $\mathrm{P}_{2} \mathrm{O}_{5}<0.05 \%$ 是例外, 这些花岗岩样品均来自 Bullenbalong超单元, 是从低 $\mathrm{P}_{2} \mathrm{O}_{5}$ 岩浆中结晶的, 而 其母岩浆中的残留体含有很高的 $\mathrm{P}_{2} \mathrm{O}_{5}$. 欧洲西 Carpathian山脉的海西期I型和S型花岗岩也有类似的 $\mathrm{SiO}_{2}-\mathrm{P}_{2} \mathrm{O}_{5}$ 相关关系 ${ }^{[25]}$.

本文对华南一些典型的I型和S型花岗岩的岩石 化学数据做了总结, 其中I型花岗岩包括三峡地区的 新元古代黄陵TTG岩套 ${ }^{[27]}$ 、粤西阳春侏罗纪的岗尾轮水高钾钙碱性花岗闪长岩 ${ }^{[28]}$ 以及福建沿海的白严 纪福州-丹阳钙碱系列花岗岩 [29]; S 型花岗岩包括新 元古代 820 Ma的江西九岭和安徽堇青石花岗岩 [27] 以及三叠纪的广西大容山(包括旧州、台马等)堇青石 花岗岩 [30]. 图 3 显示了这些典型I型和S型花岗岩的 $\mathrm{SiO}_{2}-\mathrm{P}_{2} \mathrm{O}_{5}$ 相关关系, 可以看出单个岩基或岩套I型花 岗岩的 $\mathrm{SiO}_{2}-\mathrm{P}_{2} \mathrm{O}_{5}$ 呈非常好的负相关关系，黄陵TTG 
岩套和岗尾-轮水花岗闪长岩的 $\mathrm{SiO}_{2}$ 变化范围非常大 $\left(\mathrm{SiO}_{2}=61 \% \sim 76 \%\right), \mathrm{P}_{2} \mathrm{O}_{5}$ 从偏基性时的 $0.2 \%$ 降低到 酸性时的 $0.04 \%$; 福州-丹阳花岗岩也有类似的 $\mathrm{SiO}_{2}$ 变化范围, $\mathrm{SiO}_{2}-\mathrm{P}_{2} \mathrm{O}_{5}$ 也呈明显的负相关关系, 只是 $\mathrm{P}_{2} \mathrm{O}_{5}$ 的变化范围更大一些，从偏基性时的 $0.24 \%$ 降 低到酸性时的 $~ 0.02 \%$ (图 3(a)). 九岭-皖南以及大容山 $\mathrm{S}$ 型堇青石花岗岩样品的 $\mathrm{SiO}_{2}=65 \% \sim 75 \%$, 与型花岗 岩相反, 所有这些堇青石花岗岩 $\mathrm{P}_{2} \mathrm{O}_{5}$ 在 $0.1 \%$ $0.2 \%$ 之 间波动, 与 $\mathrm{SiO}_{2}$ 没有相关关系(图 3(b)).

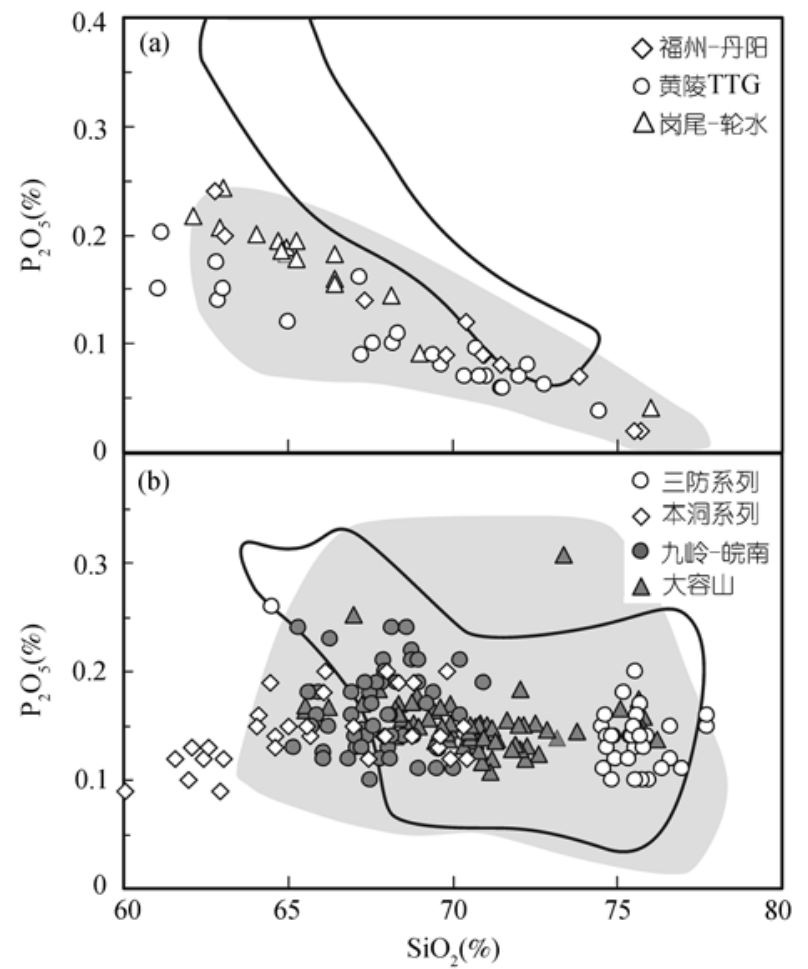

图 3 华南一些代表性 I 型和 $\mathrm{S}$ 型花岗岩的 $\mathrm{SiO}_{2}-\mathrm{P}_{2} \mathrm{O}_{5}$ 相关 关系图

阴影区和线框区分别是澳大利亚Lachlan褶皱带早古生代I型和S型花 岗岩以及欧洲西Carpathian山脉的海西期 $\mathrm{I}$ 型和 $\mathrm{S}$ 型花岗岩的分布范围 (数据来源: 文献 [25, 27 30])

图 3(b)还显示了广西北部新元古代 820 Ma的二 云母淡色花岗岩和黑云母花岗岩的数据, 二云母淡 色花岗岩包括三防、元宝山、平英、田蓬等岩体, 总 出露面积超过 $1300 \mathrm{~km}^{2}$, 造岩矿物包括石英、钾长 石、钠质斜长石、2\% 6\%黑云母和 1\% 5\%白云母. 这 些淡色花岗岩普遍富 $\mathrm{SiO}_{2}(74 \% \sim 78 \%)$ 、强过铝 $(\mathrm{A} / \mathrm{CNK}=1.08 \sim 1.24)$ 、低 $\mathrm{CaO} / \mathrm{Na}_{2} \mathrm{O}(<0.3)$ 、高 $\mathrm{Rb} / \mathrm{Sr}$ (3.4 330)、 $\mathrm{Rb} / \mathrm{Ba}(1.1 \sim 170)$, 是泥质沉积岩来源的典
型S型花岗岩 ${ }^{[27]}$. 与高分异I型花岗岩相比, 这些淡色 花岗岩的 $\mathrm{P}_{2} \mathrm{O}_{5}$ 明显较高 $(0.1 \% \sim 0.2 \%)$, 而且与 $\mathrm{SiO}_{2}$ 无 相关关系. 黑云母花岗岩包括本洞、蒙洞、寨滚、龙 有等岩体, 出露面积较小 (约 $85 \mathrm{~km}^{2}$ ), 其造岩矿物包 括石英、钾长石、斜长石和 $10 \%$ 17\%黑云母, 但不 含角闪石, 化学成分从中性变化到酸性 $\left(\mathrm{SiO}_{2}=\right.$ $60 \% \sim 70 \%)$ 、均为过铝质( $\mathrm{A} / \mathrm{CNK}=1.0 \sim 1.3)$, 有较高 的 $\mathrm{CaO} / \mathrm{Na}_{2} \mathrm{O}(>0.3)$ 和较低的 $\mathrm{Rb} / \mathrm{Sr}(0.6 \sim 1.9)$ 与 $\mathrm{Rb} / \mathrm{Ba}(0.2 \sim 0.5)$, 是富长石的砂屑质沉积岩重熔形成 的 $S$ 型花岗岩 ${ }^{[27]}$. 这些黑云母花岗岩的 $\mathrm{P}_{2} \mathrm{O}_{5}$ 含量与淡 色花岗岩相当, $\mathrm{P}_{2} \mathrm{O}_{5}$ 与 $\mathrm{SiO}_{2}$ 呈现弱的正相关关系, 其 基性端元的 $\mathrm{P}_{2} \mathrm{O}_{5}$ 约为 $0.09 \% \sim 0.13 \%$ 、酸性端元 的 $\mathrm{P}_{2} \mathrm{O}_{5}$ 约为 $0.12 \% \sim 0.2 \%$, 明显不同于高分异 $\mathrm{I}$ 型花岗 岩.

\section{2 南岭燕山早期代表性花岗岩体的成因类 型}

\section{$2.1 \sim 190$ Ma 柯树北花岗岩}

柯树北岩体出露于赣南信丰、安远交界, 出露面 积约 $300 \mathrm{~km}^{2}$, 岩性主要为中粒黑云母二长花岗岩和 黑云母钾长花岗岩, 造岩矿物组成为 20\% 30\%石英、 $45 \% \sim 55 \%$ 钾长石、15\% 25\% 奥长石 $(A n=15 \sim 30)$ 和 $5 \%$ 10\%黑云母; 副矿物主要有锆石、磷灰石、磷钇 矿和黄铁矿. 分析结果(表 1)显示出柯树北花岗岩样 品的 $\mathrm{SiO}_{2}$ 介于 $69 \% \sim 78 \%$, 过铝质 (A/CNK = 1.01 1.28, 图 3(b)), $\mathrm{P}_{2} \mathrm{O}_{5}$ 含量 $<0.08 \% . \mathrm{SiO}_{2}$ 与 $\mathrm{P}_{2} \mathrm{O}_{5}$ 呈弱的负相关关系(图 4(a)). 样品的 $\mathrm{Ga}, \mathrm{Nb}, \mathrm{Zr}$ 和 $\mathrm{Y}$ 含量高, $10000 \times \mathrm{Ga} / \mathrm{Al}=2.7 \sim 4.3$, 是典型的铝质 $\mathrm{A}$ 型 花岗岩(图 4(b), (c)).

\section{2 第 I 阶段 A 型花岗岩}

代表性的 $\mathrm{A}$ 型花岗岩是赣南的寨背和陂头岩体. 寨背花岗岩位于柯树北岩体之南, 出露面积约 $300 \mathrm{~km}^{2}$, 岩性主要为粗粒钾长花岗岩, SHRIMP锆石 $\mathrm{U}-\mathrm{Pb}$ 年龄为 $(172 \pm 5) \mathrm{Ma}$, 与共生的车步辉长岩的 SHRIMP锆石U-Pb年龄 $(173 \pm 4) \mathrm{Ma}$ 完全一致 ${ }^{[10]}$; 陂头 岩体位于粤北-赣南交界、寨背岩体之西, 出露面积 约 $1250 \mathrm{~km}^{2}, \mathrm{Rb}-\mathrm{Sr}$ 全岩等时线年龄约 $178 \mathrm{Ma}^{[31]}$. 寨 背和陂头花岗岩在岩性、矿物组合、岩石化学和地球 化学特征上与柯树北岩体非常相似(图 4(a), (b)), $10000 \times \mathrm{Ga} / \mathrm{Al}=2.7 \sim 4.3$, 也是典型的铝质 $\mathrm{A}$ 型花岗岩 (图 4(c)). 

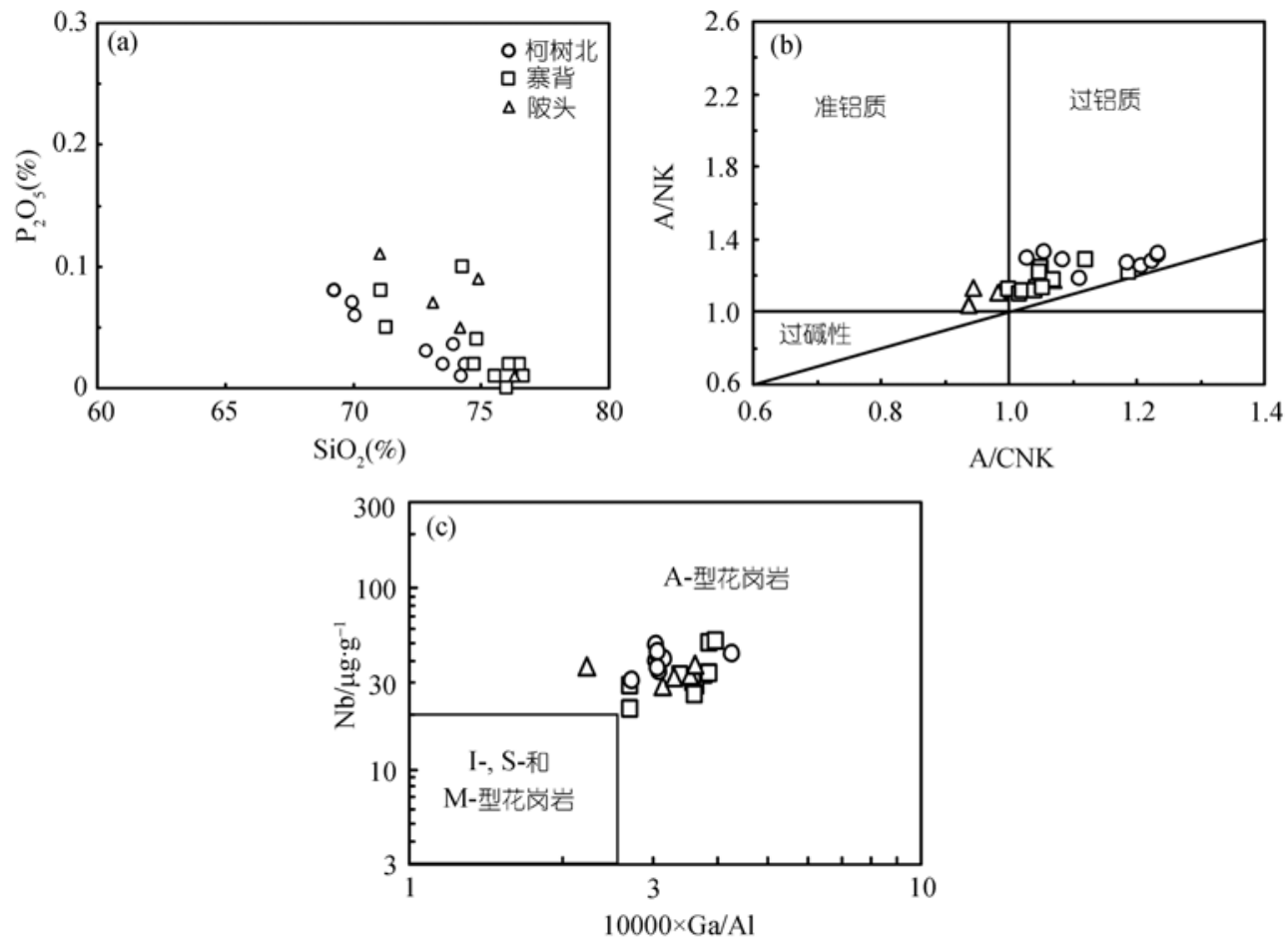

图 $4 \sim 190 \mathrm{Ma}$ 柯树北岩体和南岭第 I 阶段 $\mathrm{A}$ 型花岗岩的 $\mathrm{SiO}_{2}-\mathrm{P}_{2} \mathrm{O}_{5}$ 相关图(a)、A/CNK-A/NK图(b)和

$\mathrm{Ga} / \mathrm{Al}-\mathrm{Nb}$ 相关图(c) (数据来源: 文献 [10,31]、本文)

表 1 柯树北岩体主量元素和微量元素分析结果 ${ }^{\text {a) }}$

\begin{tabular}{|c|c|c|c|c|c|c|c|c|c|}
\hline & 2KGN38.1 & 2KGN38.2 & 2KGN38.4 & 2KGN39.1 & 2KGN39.2 & 2KGN40.3 & 2KGN40.4 & 2KGN40.5 & 2KGN40.7 \\
\hline \multicolumn{10}{|c|}{ 主量元素(\%) } \\
\hline $\mathrm{SiO}_{2}$ & 69.27 & 69.97 & 70.09 & 74.25 & 74.4 & 72.85 & 73.53 & 73.93 & 72.86 \\
\hline $\mathrm{TiO}_{2}$ & 0.37 & 0.31 & 0.32 & 0.14 & 0.16 & 0.2 & 0.17 & 0.19 & 0.21 \\
\hline $\mathrm{Al}_{2} \mathrm{O}_{3}$ & 13.73 & 13.71 & 14.15 & 13.84 & 13.45 & 14.36 & 14.18 & 13.67 & 14.22 \\
\hline $\mathrm{Fe}_{2} \mathrm{O}_{3}{ }^{\mathrm{T}}$ & 3.78 & 3.18 & 3.29 & 1.6 & 1.63 & 2.19 & 2.03 & 2.03 & 2.05 \\
\hline $\mathrm{MnO}$ & 0.07 & 0.06 & 0.05 & 0.01 & 0.02 & 0.02 & 0.02 & 0.02 & 0.02 \\
\hline $\mathrm{MgO}$ & 0.44 & 0.31 & 0.35 & 0.17 & 0.2 & 0.22 & 0.19 & 0.21 & 0.23 \\
\hline $\mathrm{CaO}$ & 1.48 & 1.51 & 1.14 & 0.24 & 0.25 & 0.4 & 0.45 & 0.44 & 0.41 \\
\hline $\mathrm{Na}_{2} \mathrm{O}$ & 3.28 & 3.35 & 3.56 & 2.94 & 2.94 & 3.29 & 3.39 & 3.61 & 3.09 \\
\hline $\mathrm{K}_{2} \mathrm{O}$ & 4.54 & 4.69 & 4.73 & 5.73 & 5.27 & 5.09 & 5.15 & 5.16 & 5.26 \\
\hline $\mathrm{P}_{2} \mathrm{O}_{5}$ & 0.08 & 0.07 & 0.06 & 0.01 & 0.02 & 0.03 & 0.02 & 0.04 & 0.03 \\
\hline LOI & 2.61 & 2.48 & 1.94 & 0.71 & 1.16 & 1.37 & 1.20 & 1.06 & 1.35 \\
\hline 总量 & 99.65 & 99.64 & 99.68 & 99.64 & 99.50 & 100.02 & 100.33 & 100.35 & 99.73 \\
\hline \multicolumn{10}{|c|}{ 微量元素/ $\mu \mathrm{g} \cdot \mathrm{g}^{-1}$} \\
\hline Ga & 22 & 22 & 23 & 20 & 22 & 24 & 23 & 31 & 23 \\
\hline $\mathrm{Rb}$ & 176 & 192 & 193 & 274 & 249 & 248 & 251 & 245 & 254 \\
\hline $\mathrm{Sr}$ & 79 & 74 & 78 & 36 & 37 & 27 & 29 & 27 & 26 \\
\hline $\mathrm{Ba}$ & 389 & 385 & 332 & 293 & 257 & 322 & 317 & 310 & 288 \\
\hline $\mathrm{Zr}$ & 304 & 265 & 261 & 139 & 169 & 241 & 200 & 240 & 240 \\
\hline $\mathrm{Nb}$ & 49 & 40 & 42 & 31 & 35 & 41 & 36 & 43 & 44 \\
\hline Th & 27 & 23 & 18 & 56 & 71 & 18 & 16 & 24 & 20 \\
\hline $\mathrm{Y}$ & 56 & 50 & 51 & 25 & 30 & 46 & 42 & 55 & 47 \\
\hline $\mathrm{Ce}$ & 161 & 158 & 145 & 78 & 100 & 107 & 118 & 104 & 110 \\
\hline
\end{tabular}




\section{3 第 II 阶段“南岭系列”花岗岩}

“南岭系列”花岗岩的岩石类型以黑云母二长花 岗岩和黑云母钾长花岗岩为主, 以及少量花岗闪长 岩、二云母花岗岩和(含石榴子石)白云母花岗岩等. 黑云母二长花岗岩和黑云母钾长花岗岩占所有出露 花岗岩面积的 $85 \%$ 以上, 高精度锆石U-Pb年龄主要 集中在 155 165 Ma之间 [32]. 我们收集了既有准确 的年龄、又有比较系统的岩石化学分析资料的一些代 表性岩体进行分析，包括花山-姑婆山 [33,34]、骑田岭 [35]、武平 ${ }^{[36]}$ 、佛冈-新丰江 ${ }^{[5,37]}$ 、九峰 ${ }^{[38]}$ 、大东山 ${ }^{[39]}$ 、

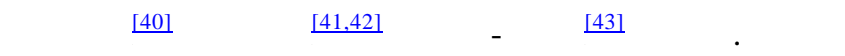
岩体所有样品的 $\mathrm{SiO}_{2}$ 为 $63 \% \sim 78 \%$ (其中有约一半样 品的 $\left.\mathrm{SiO}_{2} \geq 73 \%\right), \mathrm{P}_{2} \mathrm{O}_{5} \leq 0.36 \%, \mathrm{SiO}_{2}-\mathrm{P}_{2} \mathrm{O}_{5}$ 呈明显的 负相关关系, 其中绝大多数超酸性 $\left(\mathrm{SiO}_{2}>75 \%\right)$ 花岗 岩样品的 $\mathrm{P}_{2} \mathrm{O}_{5} \leq 0.05 \%$ (图 5(a)). 所有样品的 $\mathrm{A} / \mathrm{CNK}=$ $0.86 \sim 1.47$, 其中绝多数样品集中在 $\mathrm{A} / \mathrm{CNK}=0.90 \sim$ 1.15(图 5(b)), 总体上为准铝质到弱过铝质, A/CNK与 $\mathrm{SiO}_{2}$ 呈弱的正相关关系 (图略)， $\mathrm{SiO}_{2}>73 \%$ 高硅花岗岩样品的 $\mathrm{A} / \mathrm{CNK}=0.93 \sim 1.47$, 变化范围几 乎相当于所有花岗岩样品, 但其中只有少数为强过 铝质花岗岩 $(A / C N K>1.15)$.

\section{4 第 II 阶段铝质 $\mathbf{A}$ 型花岗岩}

代表性的 $A$ 型花岗岩是南昆山和西山两个岩体. 南昆山岩体位于广东龙口县(佛冈岩体东南侧), 出露 面积约 $200 \mathrm{~km}^{2}$, 是一个典型的碱性花岗岩, 造岩矿 物组成为 $23 \% \sim 36 \%$ 石英, $24 \% \sim 48 \%$ 条纹长石, $14 \% \sim 18 \%$ 钠长石 $\left(\mathrm{An}_{0-5}\right), 2 \% \sim 5 \%$ 黑鳞云母、0.3\% $0.5 \%$ 白云母 ${ }^{[44]}$, 并且含铌铁矿和铁橄榄石 ${ }^{[18]}$, 岩体 的SHRIMP锆石U-Pb年龄为 $158 \mathrm{Ma}^{[5]}$. 西山岩体位于 湘-粤交界的九嶷山花岗岩带东部, 出露面积约为 $700 \mathrm{~km}^{2}$, 为一规模较大的中浅成-喷发过渡类型的火 山-侵入杂岩, 包括中细粒斑状黑云母二长和正长花
岗岩、花岗斑岩、微细粒花岗质碎斑熔和英安流纹 (斑)岩, 含少量铁橄榄石和铁辉石, 属于一个剥蚀较 深的破火山机构中不同产状的一套岩石, SHRIMP 锆石 U-Pb和Rb-Sr等时线年龄为 $156 \mathrm{Ma}^{[45]}$. 这两个岩 体矿物组成类似, 特别都含有少量铁橄榄石, 属于典 型的碱性花岗质岩石.

西山岩体的 $\mathrm{SiO}_{2}$ 为 $66 \% \sim 75 \%, \mathrm{P}_{2} \mathrm{O}_{5}$ 为 $0.06 \% \sim$ $0.3 \%$, 变化范围较大而且两者具有很好的负相关关 系, 显示出从中酸性到强酸性的完整演化趋势, 大多 数样品的 $\mathrm{A} / \mathrm{CNK}$ 为 $1.0 \sim 1.1$ (图 6); 而南昆山花岗岩 则都是高度分异的强酸性岩石, 岩石化学成分相当 均一, $\mathrm{SiO}_{2}$ 为 $76.6 \% \pm 0.4 \%, \mathrm{P}_{2} \mathrm{O}_{5}<0.1 \%, \mathrm{~A} / \mathrm{CNK}$ 为 $0.996 \pm 0.024$ (图 6). 两个岩体的样品均高度富集高场 强元素、REE 和 Ga, 西山岩体和南昆山岩体的 10000 $\times \mathrm{Ga} / \mathrm{Al}$ 分别为 $2.6 \sim 3.4$ 和 $4.0 \sim 5.5$, 是典型的铝质 A 型花岗岩.

\section{5 第 II 阶段成矿花岗岩}

一些“南岭系列”花岗岩的高分异相与W, Sn, Mo, $\mathrm{Bi}, \mathrm{Nb}, \mathrm{Ta}$ 等稀有多金属超大型矿床有非常密切的关 系, 如千里山 ${ }^{[46]}$ 、大吉山-漂塘 ${ }^{[47,48]}$ 和西华山 ${ }^{[49]}$ 等, 均以小岩株形式产出, 例如千里山花岗岩约为 9.8 $\mathrm{km}^{2}$ 、大吉山和漂塘花岗岩为隐伏岩体, 矿区面积均约 为 $4.8 \mathrm{~km}^{2}$ 、西华山花岗岩约为 $19.1 \mathrm{~km}^{2}$. 这些花岗岩 的主要岩性是黑云母花岗岩、二云母花岗岩和白云母花 岗 岩, 以石英脉、夕卡岩和云英岩等成矿类型为主, 成 岩和成矿年龄非常一致, 主要集中在 $150 \sim 160$ $\mathrm{Ma}{ }^{[50 \sim 52]}$.

在岩石化学上, 千里山、大吉山-漂塘和西华山 都是超酸性过铝质花岗岩, 绝大多数样品 $\mathrm{SiO}_{2}$ 为 $73 \% \sim 78 \%, \mathrm{~A} / \mathrm{CNK}$ 为 $1.0 \sim 1.3, \mathrm{P}_{2} \mathrm{O}_{5}$ 含量很低, 大多 数样品 $\mathrm{P}_{2} \mathrm{O}_{5} \leq 0.05 \%$, 并且与 $\mathrm{SiO}_{2}$ 呈弱的负相关关系
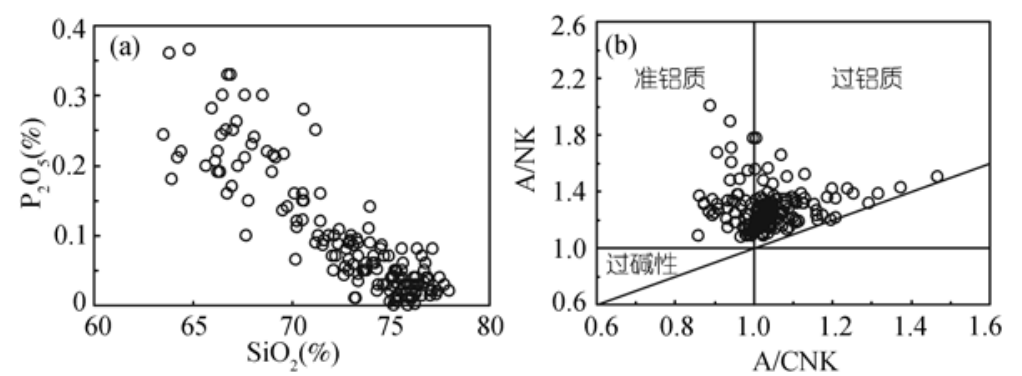

图 5 南岭第 II 阶段“南岭系列” 花岗岩代表性岩体的 $\mathrm{SiO}_{2}-\mathrm{P}_{2} \mathrm{O}_{5}$ 相关图(a)和A/CNK-A/NK图(b)

(数据来源: 文献 [5, 33 43]) 

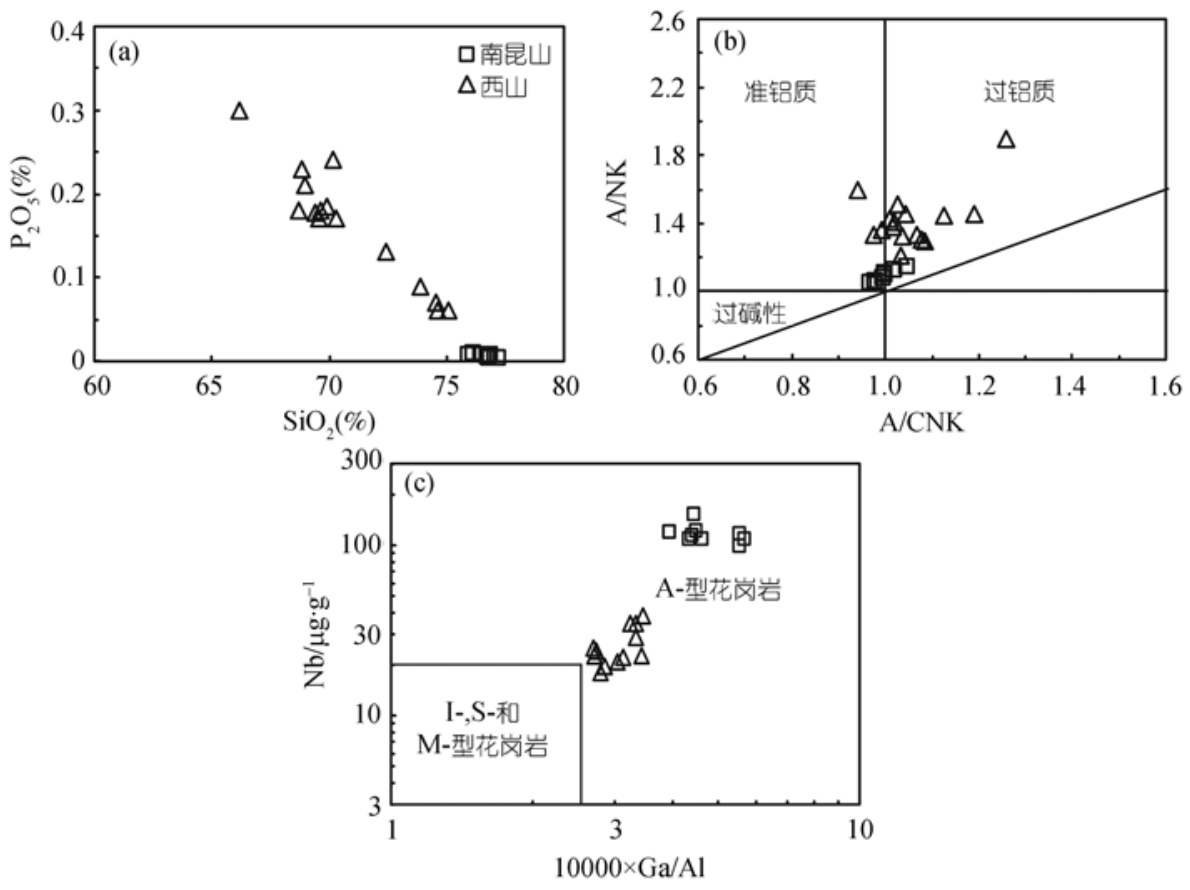

图 6 南岭第 II 阶段A型花岗岩代表性岩体的 $\mathrm{SiO}_{2}-\mathrm{P}_{2} \mathrm{O}_{5}$ 相关图(a)、A/CNK- A/NK图(b)和Ga/Al-Nb相关图(c) (数据来源: 文献 [5, 45])

(图 7). 二云母和白云母花岗岩通常有很高含量的 $\mathrm{Li}$, $\mathrm{Be}, \mathrm{Rb}, \mathrm{Nb}, \mathrm{Th}, \mathrm{U}$ 以及HREE, 在球粒陨石标准化图 上, REE呈“V型”(或“海鸥式”)的分布形式，并有明显 的“四分组”效应 $[46,53]$, 表明岩石经历了很高程度的 分异演化和岩浆-流体相互作用.

\section{3 讨论}

\section{1 燕山早期“南岭系列”花岗岩的成因类型}

在“南岭系列” 花岗岩里, 只有少数含有角闪石 的花岗闪长岩和二长花岗岩可以确认为 I 型花岗岩. 出露面积占绝大多数的是不含角闪石的黑云母二长 花岗岩、黑云母钾长花岗岩, 同时还有少数高演化的 二云母和白云母花岗岩, 在许多文献中一般把这些 黑云母二长花岗岩 $\rightarrow$ 黑云母钾长花岗岩 $\rightarrow$ 二云母花 岗岩 $\rightarrow$ 白云母花岗岩系列划分成“陆壳改造型” 花岗 岩, 相当于 $\mathrm{S}$ 型花岗岩. 然而, 本文的分析表明, 这 些“南岭系列”花岗岩的 $\mathrm{P}_{2} \mathrm{O}_{5}$ 和 $\mathrm{SiO}_{2}$ 呈明显的负相关 关系, 高硅强分异花岗岩不仅 $\mathrm{P}_{2} \mathrm{O}_{5}$ 含量很低(大多数 小于 $0.05 \%$ ), 而且大多数为准铝质-弱过铝质 (A/CNK 为 $0.93 \sim 1.15$ ), 只有极少数样品(特别是部分成矿花岗 岩)的 A/CNK >1.15. “南岭系列”花岗岩的 $\mathrm{P}_{2} \mathrm{O}_{5}-\mathrm{SiO}_{2}$ 相 关关系与准铝质-弱过铝质 $\mathrm{I} /$ 型花岗岩非常类似, $\mathrm{\text { 表 }}$
明在岩浆演化早期发生了磷灰石的分离结晶, 它们 的母岩浆应该是准铝质/弱过铝质的, 因此“南岭系 列”花岗岩应该属于分异 I 型花岗岩, 而不是强过铝 质 $\mathrm{S}$ 型花岗岩. 极少数高硅强分异花岗岩有高的 A/CNK 值 $(>1.2)$, 可能和岩浆演化晚期的岩浆-流体 相互作用有关(表现出“海鸥式”的 REE 分布图形和 “四分组”效应). 此外, 蚀变/交代作用也有可能导致 $\mathrm{K}, \mathrm{Na}$ 的降低而使 A/CNK 值增高. 这些高硅强分异花 岗岩的化学组成非常接近 “最低共熔点”成分, 因此 不适合用矿物学和岩石化学特征简单地进行成因类 型分类, 最好是和其他同期共生的花岗岩一起进行 共生成因类型组合研究.

高 $\mathrm{SiO}_{2}$ 、低 $\mathrm{P}_{2} \mathrm{O}_{5}$ (或 $\mathrm{P}_{2} \mathrm{O}_{5}-\mathrm{SiO}_{2}$ 负相关关系)并不是 判断分异I型花岗岩的唯一依据, Th和Y随岩浆结晶 分异演化的趋势也是区分花岗质岩浆是准铝质或过 铝质的有效判据 26$]$. 由于 Th和Y在过铝质岩浆演化 早期优先进入 $T h$ 和 $Y$ 富集的矿物(如独居石), 分异 $\mathrm{S}$ 型花岗岩 $\left(R b>200 \mu \mathrm{g} \cdot \mathrm{g}^{-1}\right)$ 的Th和Y含量低, 并随着 $R b$ 增加而降低; 相反, Th和Y富集的矿物不在准铝质岩 浆演化早期优先结晶, 所以分异I型花岗岩的 Th和 $Y$ 含量高, 并与 $R b$ 含量呈正相关关系. 图 8 显示了南岭 最大的花岗岩基 $9-1$ 佛冈 - 新丰江花岗岩样 

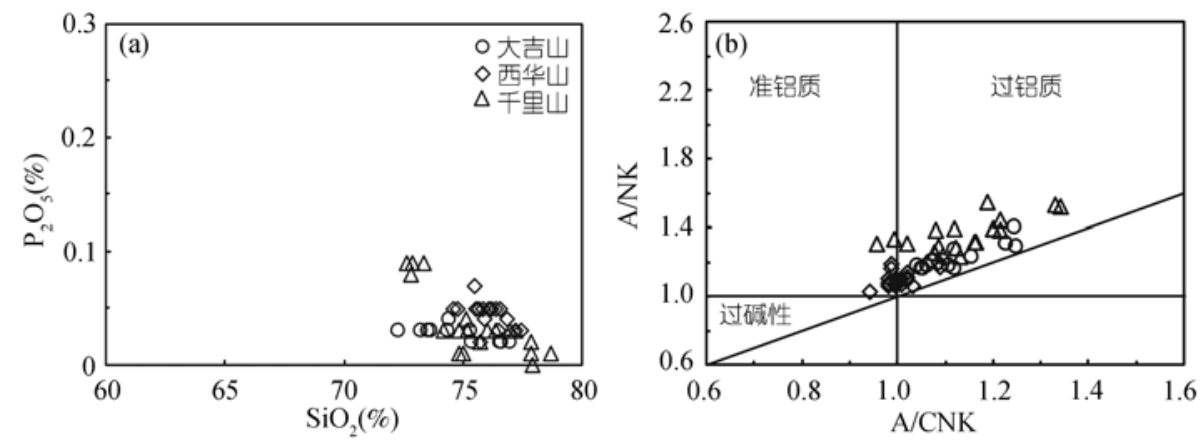

图 7 南岭第 II 阶段成矿花岗岩代表性岩体的 $\mathrm{SiO}_{2}-\mathrm{P}_{2} \mathrm{O}_{5}$ 相关图(a)和A/CNK-A/NK图(b)(数据来源: 文献 [46 49])

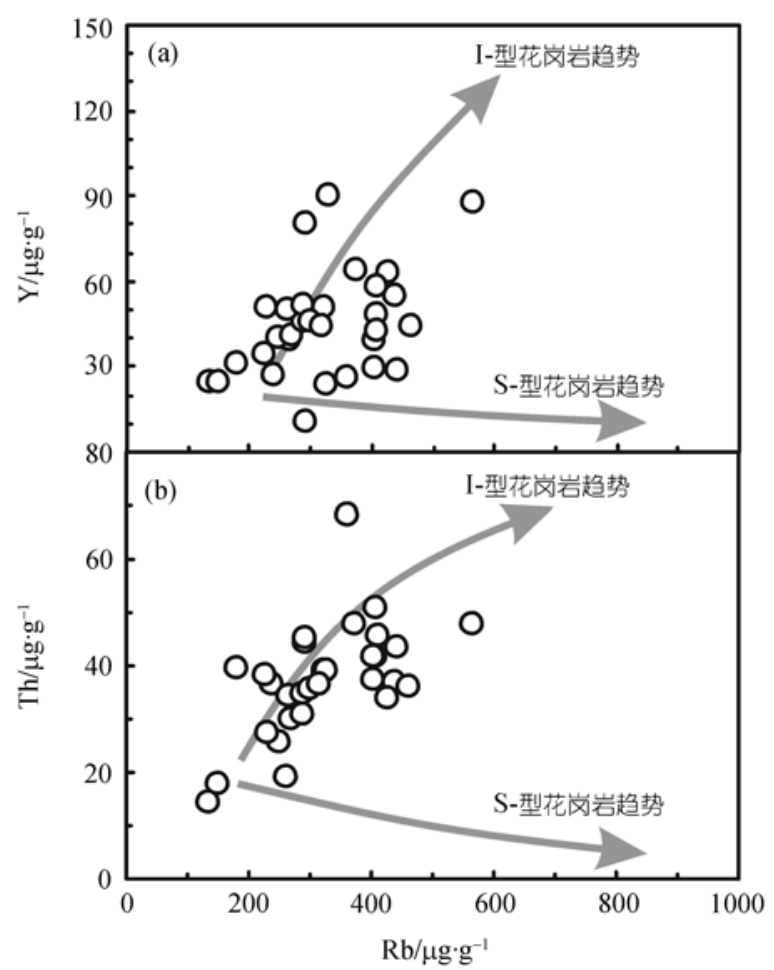

图 8 佛冈花岗岩基的Rb-Y(a)和Rb-Th相关图(b)(据Li等 ${ }^{[5]}$ ) 其中Lachlan褔彼带的I型和S 型花岗岩趋势引自Chappell ${ }^{[26]}$

品 $\mathrm{Rb}$ 和 $\mathrm{Th}, \mathrm{Y}$ 之间均为正相关关系, $\mathrm{Rb}$ 含量高(即结 晶分异程度高)的样品有很高的 $\mathrm{Th}$ 和 $\mathrm{Y}$ 含量, 与 Lachlan 褶䏢带中的 I 型花岗岩的演化趋势一致.

堇青石、白云母和石榴子石等富铝矿物的出现 通常是作为 $S$ 型花岗岩的重要矿物学依据, 例 如Lachlan褶皱带中大规模的早古生代堇青石花岗 岩、扬子块体南缘新元古代九岭-皖南堇青石花岗岩 和桂北二云母淡色花岗岩以及大容山(包括旧州、台 马等)三叠纪堇青石和石榴子石花岗岩等大型花岗岩 岩基(图 3). 而在燕山早期“南岭系列”花岗岩中出现
的含白云母花岗岩(包括成矿花岗岩)与上述典型的 $S$ 型花岗岩基不同, 大多数规模很小, 出露面积一般只 有数十或数平方公里, 而且在时-空上与黑云母二长 花岗岩、钾长花岗岩密切共生. 这些花岗岩通常只含 有白云母坧榴子石, 均未出现堇青石或矽线石. 对 这类含白云母土石榴子石花岗岩的成因类型划分常常 有不同意见 [54 56], 因为准铝质和过铝质岩浆经过分 异结晶后都可能形成白云母石榴子石. 于津海等人 [57]通过详细的矿物学研究, 论证了闽东南一些含原 生白云母和石榴子石的花岗岩属于I型花岗岩, 这些 花岗岩中的石榴子石以富 $\mathrm{Mn}, \mathrm{Fe}$ 和贫 $\mathrm{Mg}$, Ca为特征, 白云母以高 $\mathrm{Fe}$ 和低 $\mathrm{Al}, \mathrm{Na}$ 为特征, 它们是岩浆高度结 晶分异演化的产物. 因此对“南岭系列”花岗岩中的 含白云母花岗岩的成因类型划分的关键是在于如何 判断其源岩是火成岩还是沉积岩. 一般说来, 堇青石 是划分 $S$ 型花岗岩最有用的(但不是充分和唯一的)矿 物学标志 ${ }^{[55]}$, 通过对花岗岩的野外地质、岩石共生 组合关系、矿物学、岩石化学、地球化学和同位素组 成的系统研究, 以确定花岗岩的源岩性质, 才能准确 划分花岗岩的成因类型.

I 型和 $S$ 型花岗岩成因分类的岩石化学基础是 $\mathrm{Na}, \mathrm{Ca}, \mathrm{Sr}$ 在长石风化形成粘土的过程中发生丢失而 使沉积岩成为过铝质(并非 $\mathrm{Al}$ 增高), 因此 S 型花岗岩 的岩石化学继承了源岩的过铝质特征, 其 $\mathrm{Na}, \mathrm{Ca}, \mathrm{Sr}$ 明显低于 I 型花岗岩. 本文以磷灰石在强过铝质和准 铝质/弱过铝质花岗岩浆中溶解度的差异为基础, 通 过系统研究一套共生演化系列花岗岩样品的 $\mathrm{SiO}_{2}-\mathrm{P}_{2} \mathrm{O}_{5}$ 相关关系, 对分异花岗岩的原始岩浆性质 进行判断. 结果表明, “南岭系列”中一些含白云母花 岗岩应是准铝质/弱过铝质岩浆经过高度结晶分异演 化的产物, 它们和共生的黑云母花岗岩同属于分异 I 
型花岗岩, 明显不同于桂北新元古代 S 型淡色花岗 岩.

南岭及邻区燕山早期大规模分异I型花岗岩厘定 的一个重要意义是, 这些花岗岩的源岩应该是以火 成岩为主, 而不是(变质)沉积岩. 锆石Hf同位素结果 显示, 少量新生地壳和/或地幔分异物质很可能参与 了这些花岗岩的形成 ${ }^{[5,36,58]}$. 因此, 这些分异I型花岗 岩的地球化学和同位素组成代表的是其火成岩源岩 的组成, 但不能完全代表华南陆壳变质基底的组成.

\section{2 南岭燕山早期火成岩组合}

花岗岩成因分类、物质来源和形成演化研究的一 个重要的地球动力学意义是了解花岗岩形成的构造 背景, 有许多学者在这方面进行了大量的研究, 例如 花岗岩构造环境分类 ${ }^{[59,60]}$ 和花岗岩形成构造环境的 微量元素地球化学判别图 [61,62]. 然而大量的研究表 明, 单纯依靠花岗岩成因类型和地球化学组成来判 别花岗岩形成的构造背景是很困难和不确定的, 一 个重要的原因在于花岗岩的地球化学往往是其源岩 以及部分熔融和结晶分异演化历史的综合反应, 花 岗岩的地球化学判别常常给出的是其源岩的构造环 境而不是花岗岩本身的形成环境, 或者没有明确的 构造意义 ${ }^{[63]}$. 例如, I型花岗岩可以形成在前造山、同 造山、晚造山甚至非造山等许多不同的构造背景, 既 便是过去一般认为形成于“同碰撞”造山环境的S型花 岗岩很多情况下可能是形成于晚造山和后造山期的 地壳伸展阶段 ${ }^{[64]}$, 甚至有可能形成于非造山环境 ${ }^{[27]}$. $\mathrm{A}$ 型花岗岩可能有不同的物质来源和成因, 但都要求 高温-低压的条件, 对应于岩石圈伸展的构造背景. 值得强调的是在研究花岗岩物质来源的同时, 应该 更加关注花岗岩形成的热来源, 因为正常的地温梯 度很难提供足够的热使地壳发生部分熔融. 因此, 综 合的地质(包括构造、变质、沉积、盆地演化)、地球 化学和地质年代学研究才有可能对花岗岩形成的构 造背景做出比较可靠的判断, 就岩石地球化学本身 而言, 应该特别注重火成岩组合的研究, 特别是幔源 玄武质岩石和碱性岩的研究.

南岭燕山早期的火成岩是华南约 270 190 Ma 印支期造山运动 ${ }^{[6,65]}$ 后的板内岩浆活动, 起始于约 $190 \mathrm{Ma}$ ，以赣南的柯树北 $\mathrm{A}$ 型花岗岩的形成为代表. 在 $180 \sim 170 \mathrm{Ma}$ 期间出现了以玄武岩和 $\mathrm{A}$ 型酸性火山 岩及其侵入相辉长岩和 $A$ 型花岗岩的“双峰式”火成岩 组合为特征的第 I 阶段火成岩. 这些火成岩虽然规
模较小, 但分布非常广泛, 包括湘南宁远-新田碱性 玄武岩 [11]、湘东南宜章长城岭拉斑玄武岩 [66]、 赣南龙南东坑一临江盆地和寻乌白面石-菖蒲盆地拉 斑玄武岩 [8,9]、赣中吉安安塘碱性玄武岩 [67]和闽西南 永定盆地拉斑玄武岩 [68]. 这些玄武岩均显示出洋岛 玄武岩(OIB)的地球化学和同位素组成特征, 为典型 的陆内裂谷玄武岩. 因此, 南岭燕山早期第 I 阶段火 成岩完全不同于活动大陆边缘火成岩组合，而和板 内非造山型火成岩组合完全一致.

紧随而来的第 II 阶段(165 150 Ma)大规模岩将 活动以分异 $I$ 型花岗岩为主, 并伴随小规模的 $A$ 型花 岗岩和正长岩. 桂东南和赣南正长岩的元素和同位 素地球化学特征与陆内“ 裂谷型” 正长岩非常相似 [10,11]，完全不同于形成于造山带的“俯冲型” 正长岩; 南昆山 $A$ 型花岗岩也显示出陆内裂谷 $A_{1}$-型花岗岩的 地球化学特征 $[5]$. 这些陆内裂谷型碱性火成岩的形 成指示南岭地区在这个时期应处于岩石圈伸展的构 造背景. 大量分异 $\mathrm{I}$ 型花岗岩的形成暗示这个时期有 很高的地热, 很可能与幔源岩浆的底侵和侵入有关. 值得注意的是, 南岭及邻区(包括从桂东南-湘南到赣 南-赣中)燕山早期的幔源玄武岩和碱性岩都一致地 表现出OIB的地球化学特征, 而不是岛弧岩石的地球 化学特征, 表明其地幔源区没有受到俯冲带流体/熔 体的交代和改造, 暗示南岭中西部地区早中生代很 可能不存在一个俯冲带之上的地幔楔. 这对于解释 华南中生代构造演化是一个重要的岩石地球化学制 约.

\section{4 小结}

磷灰石在准铝质/弱过铝质和强过铝质花岗岩浆 中的溶解度有明显的差异, 因此 I 型和 S 型花岗岩有 明显不同的岩石化学和 $\mathrm{SiO}_{2}-\mathrm{P}_{2} \mathrm{O}_{5}$ 相关关系特征, 即 I 型花岗岩的 $\mathrm{SiO}_{2}-\mathrm{P}_{2} \mathrm{O}_{5}$ 呈明显的负相关关系, 而 $\mathrm{S}$ 型 花岗岩的 $\mathrm{P}_{2} \mathrm{O}_{5}$ 随 $\mathrm{SiO}_{2}$ 的增加无明显降低的趋势. 南 岭地区燕山早期大规模的黑云母二长花岗岩和黑云 母钾长花岗岩的 $\mathrm{SiO}_{2}$ 和 $\mathrm{P}_{2} \mathrm{O}_{5}$ 呈明显的负相关关系, 属于分异 I 型花岗岩, 它们和密切共生的小规模花岗 闪长岩、二(白)云母花岗岩等构成了一个完整的准铝 质-弱过铝质的 I 型/分异I型花岗岩演化系列, 其源岩 主要为元古代火成岩, 少量新生地壳和/或地幔分异 物质可能参与了花岗岩的形成. 这些 I 型/分异 I 型花 岗岩在时空上和小规模 $\mathrm{A}$ 型酸性、基性火山/侵入岩 以及碱性岩密切共生, 构成一典型的板内非造山型 
火成岩组合. 南岭燕山早期大规模 I 型/分异 I 型花岗 岩的确认, 对深入认识南岭及邻区中生代地球动力 学背景有重要的意义.

致谢 黄会清协助数据收集整理; 刘颖帮助柯树北岩体的 地球化学分析; 三位匿名审稿人对文章提出了重要的意见 和建议, 在此一并致谢.

\section{参考 文 献}

1 Xu K, Sun N, Wang D, et al. On the origin and metallogeny of the granites in South China. In: Xu K, Tu G, eds. Geology of Granites and Their Metallogenetic Relations. Proceeding of International, Nanjing University. Beijing: Science Press, 1982. 1-3

2 王联魁, 张绍立, 杨文金, 等. 华南花岗系列类型的 $\mathrm{Sr} 、 \mathrm{O} 、 \mathrm{~Pb}$ 、 Nd 同位素与形成环境. 地质与勘探, 1989, 25: 29-33

3 王德滋. 华南花岗岩研究的回顾与展望. 高校地质学报, 2004, 10: 305-314

4 王德滋, 沈渭洲. 中国东南部花岗岩成因与地壳演化. 地学前缘, 2003, 10: 209-220

5 Li X H, Li Z X, Li W X, et al. U-Pb zircon, geochemical and Sr-Nd-Hf isotopic constraints on age and origin of Jurassic I and A-type granites from central Guangdong, SE China: A major igneous event in respond to foundering of a subducted flat-slab? Lithos, 2007, doi:10.1016/j.lithos.2006.09.018

6 Li Z X, Li X H. Formation of the $1300 \mathrm{~km}$-wide intra-continental orogen and post-orogenic magmatic province in Mesozoic South China: A flat-slab subduction model. Geology, 2007, 35: 179—182 [DOI]

7 丁兴, 陈培荣, 陈卫锋, 等. 湖南沩山花岗岩中锆石 LAICPMS $\mathrm{U}-\mathrm{Pb}$ 定年: 成岩启示和意义. 中国科学 D 辑: 地球科学, 2005, 35(7): 606-616

8 陈培荣, 孔兴功, 王银喜, 等. 赣南燕山早期双峰式火山-侵入 杂岩的 Rb-Sr 同位素定年及意义. 高校地质学报, 1999, 5: 367383

9 陈培荣, 孔兴功, 倪琦生, 等. 赣南燕山早期双峰式火山的厘定 和意义. 地质论评, 1999, 45(增刊): 734-741

10 Li X H, Chen Z G, Liu D Y, et al. Jurassic gabbro-granite-syenite suites from southern Jiangxi Province, SE China: Age, origin and tectonic significance. Int Geol Rev, 2003, 45: 898-921

11 Li X H, Chung S L, Zhou H W, et al. Jurassic intraplate magmatism in southern Hunan-eastern Guangxi: ${ }^{40} \mathrm{Ar} /{ }^{39} \mathrm{Ar}$ dating, geochemistry, Sr-Nd isotopes and implications for tectonic evolution of SE China. In: Malpas J, Fletcher C J, Aitchison J C, et al, eds. Aspects of the Tectonic Evolution of China. London: Geological Society London Special Publications, 2004. 193-216

12 谢昕, 徐夕生, 邹海波, 等. 中国东南部晚中生代大规模岩浆作 用序幕: $J_{2}$ 早期玄武岩. 中国科学 D 辑: 地球科学, 2005, 35(7): 587-605

13 王岳军, 范蔚茗, 郭锋, 等. 湘东南中生代花岗闪长岩锆石 U-Pb 法定年及其成因指示. 中国科学 D 辑: 地球科学, 2001，31(9): $745-751$

14 Wang Q, Xu J F, Jian P, et al. Petrogenesis of adakitic porphyries in an extensional tectonic setting, Dexing, South China: Implications for the genesis of porphyry copper mineralization. J Petrol,
2006, 47: 119-141 [DOI]

15 赵子杰, 马大铨, 林惠坤, 等. 广东龙窝、佛冈花岗岩类岩体地 球化学特征及其形成地质背景. 南岭地质矿产科研报告集(第一 集). 武汉: 武汉地质学院出版社, 1986. 28-67

16 庄文明, 陈绍前, 黄友义. 佛冈复式岩体地质地球化学特征及其 成岩源岩. 广东地质, 2000, 15: 1-12

17 陈小明, 王汝成, 刘昌实, 等. 广东从化佛冈(主体)黑云母花岗 岩定年和成因. 高校地质学报, 2002, 8: 293-307

18 包志伟, 赵振华. 佛冈铝质 $\mathrm{A}$ 型花岗岩的地球化学及其形成环 境初探. 地质地球化学, 2003, 31: 52-61

19 Watson E B. Apatite saturation in basic to intermediate magmas. Geophys Res Lett, 1979, 6: 937—940

20 Watson E B, Capobianco C J. Phosphorus and the rare earth elements in felsic magmas: An assessment of the role of apatite. Geochim Cosmochim Acta, 1981, 45: 2349—2358 [DOI]

21 Green T H, Watson E B. Crystallization of apatite in natural magmas under high pressure, hydrous conditions, with particular reference to "orogenic" rock series. Contrib Mineral Petrol, 1982, 79: 96-105 [DOI]

22 Harrison T M, Watson E B. The behavior of apatite during crustal anatexis: Equilibrium and kinetic considerations. Geochim Cosmochim Acta, 1984, 48: 1468-1477 [DOI]

23 Wolf M B, London D. Apatite dissolution into peraluminous haplogranitic melts: An experimental study of solubilities and mechanism. Geochim Cosmochim Acta, 1994, 58: 4127-4145 [DOI]

24 London D, Wolf M B, Morgan V I, et al. Experimental silicate-phosphate equilibria in peraluminous granitic magmas, with a case study of the alburquerque batholith at Tres Arroyos, Badajoz, Spain. J Petrol, 1999, 40: 215-240 [DOI]

25 Broska I, Williams C T, Uher P. The geochemistry of phosphorus in different granite suites of the western Carpathians, Slovakia: The role of apatite and P-bearing feldspar. Chem Geol, 2004, 205: 115 [DOI]

26 Chappell B W. Aluminium saturation in I and S-type granites and the characterization of fractionated haplogranites. Lithos, 1999, 46: 535-551 [DOI]

27 Li X H, Li Z X, Ge W, et al. Neoproterozoic granitoids in South China: Crustal melting above a mantle plume at ca. 825 Ma? Precambrian Res, 2003, 122: 45-83 [DOI]

28 李献华, 周汉文, 刘颖, 等. 粤西阳春中生代钾玄质侵入岩及其 构造意义：1. 岩石学和同位素地质年代学. 地球化学, 2000, 29 513-520

29 Martin H, Bonin B, Capdevila R, et al. The Kuiqi peralkaline granitic complex (SE China)-petrology and geochemistry. J Petrol, 1994, 35: 983-1015

30 祁昌实, 邓希光, 李武显, 等. 桂东南大容山-十万大山 S 型花岗 岩带的成因: 地球化学及 Sr-Nd-Hf 同位素制约. 岩石学报, 2007, 23: 403-412

31 范春方, 陈培荣. 赣南陂头花岗岩体 Nd-Sr 同位素特征及其意义 地质找矿论丛, 2000, 15: 282-287

$32 \mathrm{Li} \mathrm{X} \mathrm{H.} \mathrm{Cretaceous} \mathrm{magmatism} \mathrm{and} \mathrm{lithospheric} \mathrm{extension} \mathrm{in}$ Southeast China. J Asian Earth Sci, 2000, 18: 293-305 [DOI]

33 朱金初, 李向东, 沈渭洲, 等. 广西花山复式花岗岩体成因的 锶、钕和氧同位素研究. 地质学报, 1989, 3: 225-235

34 朱金初, 李向东. 广西花山花岗岩的岩石学和地球化学特征及 
成岩物质来源地探讨. 岩石矿物学杂志, 1988, 7: 28-38

35 邓希光, 李献华, 刘义茂, 等. 骑田岭花岗岩体的地球化学特征 及其对成矿的制约. 岩石矿物学杂志, 2005, 24: 93-102

36 于津海, 周新民, 赵蕾, 等. 壳幔作用导致武平花岗岩形成一 Sr-Nd-Hf-U-Pb 同位素证据. 岩石学报, 2005, 21: 651-664

37 刘昌实, 陈小明, 王汝成, 等. 下地壳部分熔融的产物: 燕山早 期广东腊圃花岗岩成因. 高校地质学报, 2005, 11(3): 343-357

38 袁忠信, 倪云祥, 吴澄宇, 等. 湘南粤北花岗岩类岩石成因的痕 量元素模拟. 岩石矿物学杂志, 1993, 12: 97-107

39 张敏, 陈培荣, 张文兰, 等. 南岭中段大东山花岗岩体的地球化 学特征和成因. 地球化学, 2003, 32: 529-539

40 邱检生, 胡建, 王孝磊, 等. 广东河源白石冈岩体: 一个高分异 的 I 型花岗岩. 地质学报, 2005, 79: 504-514

41 付建明, 马昌前, 谢才富, 等. 湖南金鸡岭铝质 $\mathrm{A}$ 型花岗岩的厘 定及构造环境分析. 地球化学, 2005, 34: 215-226

42 章邦桐, 戴永善, 王驹, 等. 南岭西段金鸡岭复式花岗岩基地质 及岩浆动力学特征. 高校地质学报, 2001, 7: 50-61

43 李建红, 卫三元, 梁良, 等. 贵东岩体地质地球化学特征及其形 成的构造环境识别. 铀矿地质, 2004, 20: 321-329

44 刘昌实, 陈小明, 王汝成, 等. 广东龙口南昆山铝质 $\mathrm{A}$ 型花岗岩 的成因. 岩石矿物学杂志, 2003, 22: 1-10

45 付建明, 马昌前, 谢才富, 等. 湘南西山铝质 A 型花岗质火山侵 入杂岩的地球化学及其形成环境. 地球科学与环境学报, 2004, 26: $15-23$

46 毛景文, 李红艳, 裴荣富. 千里山花岗岩体地质地球化学及与成 矿关系. 矿床地质, 1995, 14: 12-25

47 孙恭安, 史明魁, 张宏良, 等. 大吉山花岗岩体岩石学、地球化 学及成矿作用的研究. 南岭地质矿产科研报告集(第二集). 武汉: 中国地质大学出版社, 1989. 326-363

48 华仁民, 张文兰, 陈培荣, 等. 赣南大吉山与漂塘花岗岩及有关 成矿作用特征对比. 高校地质学报, 2003, 9: 609-619

49 吴永乐, 梅勇文, 刘鹏程, 等. 西华山铇矿地质. 北京: 地质出 版社, 1987. 319

50 Maruejol P, Cuney M, Turpin L. Magmatic and hydrothermal REE fractionation in the Xihuashan granites (SE China). Contrib Minera1 Petro1, 1990, 104: 668-680 [DOI]

51 Li X H, Liu D Y, Sun M, et al. Precise Sm-Nd and U-Pb isotopic dating of the super-giant Shizhuyuan polymetallic deposit and its host granite, Southeast China. Geol Mag, 2004, 141: 225-231 [DOI]

52 蒋国豪, 胡瑞忠, 谢桂青, 等. 江西大吉山铇矿成矿年代学研究. 矿物学报, 2004, 24: 253-256
53 Zhao Z H, Xiong X L, Han X D, et al. Controls on the REE tetrad effect in granites: Evidence from the Qianlishan and Baerzhe granites, China. Geochem J, 2002, 36: 527—543

54 White A J R, Clemens J D, Holloway J R, et al. S-type granites and their probable absence in southwestern North America. Geology, 1986, 14: 115-118 [DOI]

55 White A J R, Clemens J D, Holloway J R, et al. Comment and reply on "S-type granites and their probable absence in southwestern North America”. Geology, 1986, 14: 805-806 [DOI]

56 Miller C F. Comment and reply on "S-type granites and their probable absence in southwestern North America”. Geology, 1986, 14: 804-805 [DOI]

57 于津海, 赵蕾, 周旋. 闽东南含石榴子石 I 型花岗岩的矿物学特 征及成因. 高校地质学报, 2004, 10: 365-377

58 汪相, Griffin W L, 王志成, 等. 湖南Y江桥花岗岩中锆石的 Hf 同位素地球化学. 科学通报, 2003, 48(4): 379-382

59 Pitcher W S. Granite type and tectonic environment. In: Hsü K, ed. Mountain Building Processes. London: Academic Press, 1983. $19-40$

60 Barbarin B. A review of the relationships between granitoid types, their origins and their geodynamic environments. Lithos, 1999, 46: $605-626$ [DOI]

61 Pearce J A, Harris B W, Tindle A G. Trace element discrimination diagrams for the tectonic interpretation of granitic rocks. J Petrol, 1984, 25: 956-983

62 Harris N B, Pearce J A, Tindle A G. Geochemical characteristics of collision-zone magmatism. In: Coward M P, Reis A C, eds. Collision Tectonics. Geol Soc Spec Publ, 1986, 19: 67—81

63 Frost B R, Barnes C, Collins W J, et al. A geochemical classification for granitic rocks. J Petrol, 2001, 42: 2033-2048 [DOI]

64 Clemens J D. S-type granitic magmas—- petrogenetic issues, models and evidence. Earth-Sci Rev, 2003, 61: 1-18 [DOI]

65 Li X H, Li Z X, Li W X, et al. Initiation of the indosinian orogeny in South China: Evidence for a Permian magmatic arc on the Hainan Island. J Geol, 2006, 114: 341-353 [DOI]

66 赵振华, 包志伟, 张伯友. 湘南中生代玄武岩类地球化学特征. 中国科学 D 辑: 地球科学, 1998, 28(增刊): 7-14

67 王岳军, 廖超林, 范蔚茗, 等. 赣中地区早中生代 OIB 碱性玄武 岩的厘定及构造意义. 地球化学, 2004, 33: 109-117

68 Zhou J C, Jiang S Y, Wang X L, et al. Re-Os isochron age of Fankeng basalts from Fujian of SE China and its geological significance. Geochem J, 2005, 39: 497—502 [DOI] 